\title{
The post-deposition modification of ooids by sulfate-reducing bacteria: Evidence from the Lower Jurassic in the Tethys Himalayas of southern Tibet
}

\author{
Xuan Liu ${ }^{1}$, Xi Chen ${ }^{1}$, Hanwei Yao ${ }^{1}$, Kaibo Han ${ }^{1}$, Huifang Guo ${ }^{1}$, and Arman Jafarian ${ }^{1}$ \\ ${ }^{1}$ China University of Geosciences Beijing
}

August 23, 2020

\begin{abstract}
Whether ooids are formed through biotic or abiotic progress seems to become increasingly controversial in recent decades. New studies indicate that the microbial effect could make important contributions to the construction, destruction and modification of ooids. Previous studies mainly focused on the organomineralization of carbonate minerals in ooids. This paper investigates the formation process of iron minerals in red oolitic grainstones of the Lower Jurassic Nieniexiongla Formation in the Tethyan Himalaya of southern Tibet. Petrographic studies and electron probe microanalysis revealed that the colorful minerals present in red ooids are hematites. Sulfur was detected in the hematites, which indicates that they were transformed from precursor pyrites. These hematites retain euhedral or framboid shapes of the pyrites. Hematite pseudomorphs distribute randomly in ooids and could not form a whole concentric layer of the ooids. Euhedral crystals usually have larger diameters than amorphous spheres and are scattered mostly in nuclei. Based on the distribution and morphology of hematites, we speculate that precursor pyrites were formed through metabolism of sulfate-reducing bacteria. Moreover, the timing of the pyrite formation was after the deposition but before the lithification. The decomposition of the microorganisms within the ooids by bacterial sulfate-reducing provides the HS-, the degradation of organic matters would produce spaces for the intrusion of pore water with sufficient Fe2+ to facilitate the pyrite deposition. In nuclei, the framboid aggregates of pyrites were transferred to euhedral crystals through continuous growth of the constituent microcrystals. Our study demonstrated organomineralization of sulfate-reducing bacteria mediated pyrites in carbonate ooids.
\end{abstract}

\section{Summary statement}

This paper investigates the formation process of iron minerals in red oolitic grainstones of the Lower Jurassic Nieniexiongla Formation, demonstrates organomineralization of sulfate-reducing bacteria mediated pyrites in carbonate ooids. We propose that sulfate-reducing bacteria would utilize organic matter within ooids after sedimentation, resulting changes in the mineral composition of ooids.

Keywords : Ooidal limestone; Pyrite; Hematitization; Organomineralization; Lower Jurassic Nieniexiongla Formation; Southern Tibet

\section{Introduction}

Ooids are common in the modern and ancient carbonate sediments of both marine and terrigenous environments. They were regarded as chiefly 'inorganic grains' in traditional view (Davies, Bubela, \& Ferguson, 1978; Morse \& Mackenzie, 1990), but recent studies inferred that microbes played important role in ooid construction and destruction (Summons et al., 2013; Diaz et al., 2015; Mariotti, Pruss, Summons, Newman, \& Bosak, 2018). Two pathways controlling the organomineralization in ooids are biologically induced and biologically influenced mechanisms (Diaz \& Eberli, 2018). Biologically influenced mechanism is passive mineralization, through which mucilaginous material or extracellular polymeric substances (EPS) control 
mineral nucleation (Diaz, Piggot, Eberli, \& Klaus, 2013; Diaz et al., 2014; Dupraz et al., 2009). Biologically induced mechanism is active mineralization, which generates minerals along metabolic activities (Diaz \& Eberli, 2018). Several metabolic processes have been identified throughout molecular techniques. Denitrification oxidizes organic carbon and could produce up to $19 \mathrm{~g} \mathrm{CaCO}_{3} / \mathrm{g} \mathrm{NO}_{3}-\mathrm{N}$ in 2 days (Erşan, De Belie, \& Boon, 2015), which is one of the most significant nitrogen transforming processes in ooids (Diaz, Piggot, Eberli, \& Klaus, 2013; Diaz et al., 2015). $\mathrm{CO}_{2}$ fixation by photoautotrophs has been confirmed through studies on modern (Summons et al., 2013; O'Reilly et al., 2016) and ancient ooids (Pacton et al., 2012; Li et al., 2017). It seems to be the most productive microbes in the formation of ooids (Pacton et al., 2012; Summons et al., 2013). The presence of sulfate reduction, ammonification (Diaz et al., 2014) and sulfate oxidation (Summons et al., 2013; Diaz, Piggot, Eberli, \& Klaus, 2013; Diaz et al., 2014; O'Reilly et al., 2016) bacteria in ooids has been detected through biomarker studies. However, their contributions to the formation of ooids were less investigated.

Ooids would be modified by microbes throughout their life cycle (Diaz \& Eberli, 2018) as evidenced by isotopic geochemistry studies. The precipitation and/or alteration of ooids by microbial photosynthesis would elevate $\delta^{11} \mathrm{~B}$ signal (Zhang et al., 2016). Denitrification may bring positive $\delta^{15} \mathrm{~N}$ and $\delta^{18} \mathrm{O}$ of the $\mathrm{NO}^{3-}$ in leachates of ooids (Diaz et al., 2015). Weak sulfate reduction is conjected through leachates of ooids (Diaz et al., 2015). However, the research about the modification of ooids by microbes mainly focuses on geochemical analysis rather than minerals, since carbonate minerals generated biologically (such as amorphous calcium carbonate (ACC), Duguid, Kyser, James, \& Rankey, 2010) are thought to be primary minerals during the accretion of ooids. Ooids containing iron minerals are supposed to play a significant role in tracing microbial activities since iron is an important element for the growth and evolution of organisms. For instance, the formation of many banded iron formations (BIFs) has strong connection with bacteria (Posth, Konhauser, \& Kappler, 2013; Chi Fru et al., 2013). Reddish pigment of rounded ferruginous oncoidal nucleus in European Phanerozoic red limestones is thought to be caused by iron bacteria mediated hematite (Préat, Mamet, De Ridder, Boulvain, \& Gillan, 2000; Mamet \& Préat, 2006). However, to date there are very few studies associating iron bacteria mediated organomineralization with carbonate ooids.

The Lower Jurassic Nieniexionala Formation in the Tethyan Himalayas of the southern Tibet contains thin- to medium-bedded red oolitic limestones. Although the lithology, microfacies, age and depositional environments were well studied (Han, Hu, Li, \& Garzanti, 2016; Han, Hu, Kemp, \& Li, 2018), the formation process of the red ooids has not been studied to date. Petrographic analysis shows the identified ferruginous minerals are responsible for the red color of the ooids. Iron minerals in sedimentary rocks are always thought to be related to microorganism activities (pyrites: Berner, De Leeuw, Spiro, Murchison, \& Eglinton, 1985; Raiswell \& Berner, 1986; Rickard, 2012; Wei, Chen, Wang, Yu, \& Tucker, 2012; and hematites: Préat, Mamet, De Ridder, Boulvain, \& Gillan, 2000; Mamet \& Préat, 2006) and/or ambient redox conditions (e.g., Cornell \& Schwertmann, 2003). In this paper, we studied the mineralogy composition and the forming process of the Nieniexiongla red ooids in order to identify the metabolic process of sulfate-reducing in these ooids.

\section{Geological setting}

The southern Tibet can be subdivided into five tectonic units, which are Xigaze Forearc Basin, YarlungZangbo Ophiolite, Tethyan Himalaya, Greater Himalaya and Lesser Himalaya from north to south (Fig. 1). Mesozoic strata are well-developed in the Tethyan Himalayan zone, which was divided into the Northern and the Southern subzones (Wang et al., 2005) separated by the Gyirong-Kangmar Thrust. Our study section, the Menqu section (GPS: 28 39'08'N, 86deg02'57'E), is located in the Tethyan Himalayan Southern subzone. During the Mesozoic, the Tethyan Himalaya belongs to the north margin of Indian subcontinent. The Jurassic sediments in Southern subzone are characterized by shallow-water carbonates and terrigenous rocks (Jadoul, Berra, \& Garzanti, 1998). The Jurassic sedimentary succession is composed of thick-bedded bioclastic limestones of Pupuga Formation (Fm.), ooidal limestones with sandstone intercalations of Nieniexiongla Fm., marls of Lanongla Fm., ooidal ironstones of Dingjie Fm. and clastic rocks of Menkadun Fm. from the bottom to the top (Jadoul, Berra, \& Garzanti, 1998; Wang et al., 2005; Li \& Wang, 2005; Han, Hu, Li, \& Garzanti, 2016). 
The Nieniexiongla Formation consists of gray to light-gray, thin- to medium-layered mudstones or oolitic grainstones rhythmically interbedded with sandstones ( $\mathrm{Li} \&$ Wang, 2005) and is Toarcian-Bajocian aged as indicated by ammonites (Yin, 2010). Middle to outer ramp was indicated by microfacies analysis (Han, Hu, $\mathrm{Li}$, \& Garzanti, 2016) and foraminiferal ecological research (Wan, 1989). A rapid transgressive and negative carbon isotope excursion initiated at the boundary of the Pupuga and Nieniexiongla formations is recently interpreted as the responses to the Toarcian Oceanic Anoxic Event (T-OAE, Han, Hu, Kemp, \& Li, 2018).

\section{Materials and methods}

Polished petrographic thin sections of eighty samples from the Nieniexiongla Formation in Menqu section were investigated by Nikon-LV100POL polarizing microscope. The classification of carbonate rocks we followed is the expanded Dunham (1962) classification proposed by Embry and Klovan (1971). Carbon isotope of bulk carbonate $\left(\delta^{13} \mathrm{C}\right)$ were measured for forty samples at the Carbonate Reservoir Key Laboratory, of the PetroChina Hangzhou Institute of Geology, using a GasBench II system coupled to a Delta V mass spectrometer (Thermo Fisher Scientific, Bremen, Germany). The instrument was calibrated with Chinese national carbonate standard GBW04405 $\left(\delta^{13} \mathrm{C}=0.57\right.$ delta notation, relative to VPDB. Eight oolitic grainstone thin sections were selected and studied in the CUGB lab (China University of Geosciences, Beijing) to investigate the mineral and chemical compositions. Geochemical analysis was conducted by electron probe microanalysis (EPMA-1720(1210229S)) on polished and conductively carbon coated thin sections. The oxides of Na, Ti, Si, $\mathrm{Co}, \mathrm{Mg}, \mathrm{Cr}, \mathrm{P}, \mathrm{Ni}, \mathrm{Al}, \mathrm{Mn}, \mathrm{K}, \mathrm{Fe}, \mathrm{Ca}$ were determined in this examination. Experimental method relied on general principle for electron probe microanalysis method GB/T15074-2008. A ZEISS Supra 55 field emission scanning electron microscopy (SEM) equipped with an Oxford Electrical Refrigeration Energy Dispersive Spectrometer (EDS) was used to examine the microstructure of ooids in both polished petrographic thin sections and fresh rock fragments by Secondary Electron (SE) and Backscattered Electron (BSE) modes. Prior to SEM examination, samples were washed by deionized water in ultrasonic cleaner for three times and dried to avoid contaminating, then coated by Platinum. The accelerating voltage was $15 \mathrm{kV}$ or $20 \mathrm{kV}$ and the working distance was 5 to $15 \mathrm{~mm}$.

\section{Results}

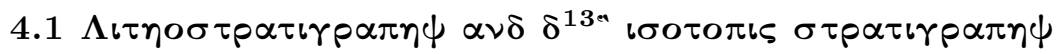

The Menqu section, which has a total thickness of $179.7 \mathrm{~m}$, is located near the Menqu village in the Nyalam area (Fig. 1). In the lower $0-11.7 \mathrm{~m}$, the carbonate rocks are composed of medium- to thick-bedded bioclastic grainstones (Fig. 2a), bioclastic wackestones (Fig. 2b) and framestones (coral reef, Fig. 2c). This part is characterized by high content of fossils, e.g., Lithiotis (Fig. 2d), corals (Fig. 2c), bivalves, gastropods (Fig. 2a), sponges and echinoderms (Fig. 2a). At the interval of $11.7-179.7 \mathrm{~m}$, the section is mainly composed of thin- to medium-bedded mudstones. Besides, texture is frequently interrupted (Fig. 2e) by siltstones, grainstones, wackestones and packstones. This part is characterized by rare fossils and much finer grains. Sedimentary structures include erosive base (Fig. 2f), sand lens (Fig. 2f) and hummocky cross-bedding.

Carbon-isotope data of the Menqu section is shown in Fig. 3. At the interval of $0-12.8 \mathrm{~m}, \delta^{13} \mathrm{C}$ values recorded by five samples range between 1.76 and 2.67 interval of $12.8-179.7 \mathrm{~m}, \delta^{13} \mathrm{C}$ values vary from 0.28 to 2.04

\subsection{Geochemical and mineralogical composition of oolitic grainstones}

Our materials come from a series of thin- to medium-bedded oolitic grainstones with total thickness of 7.2 $\mathrm{m}$ (157.2-164.4 m) near the top of the Menqu section (Fig. 3). These oolitic grainstones of the Nieniexiongla Formation consist mainly of ooids with a few bioclasts and quartz grains. Some grains are surrounded by bladed to dogtooth cement (variously shaped terminations of crystals). The intergranular space is filled by mosaic crystals which may indicate the influence of meteoric water during diagenetic process (Javanbakht, Wanas, Jafarian, Shahsavan, \& Sahraeyan, 2018). Additionally, the color, size, shape and type of ooids from the bottom to the top change gradually through the Nieniexiongla Formation. Oolitic grainstones closed to the bottom are mainly composed of gray colored ooids with diameters ranging from 300 to $500 \mu \mathrm{m}$. Diverse 
nuclei including peloids, quartz grains, bioclasts and preexisting ooids are enclosed by cortices exhibiting indistinct micritic to radial-fibrous structure. Part of the ooids have both micritic and radial-fibrous cortex, which suggests change in sea-water conditions. About $70 \%$ of the ooids are broken, compounded and regenerated ooids occurred too, part of these ooids have abraded outline (Fig. 4a). In contrast, oolitic grainstones closed to the top are mainly composed of red colored ooids. Red ooids are 200 to $400 \mu \mathrm{m}$ in size. The characteristics of their nuclei and cortices are similar with gray ooids. Most ooids are accompanied by circumgranular cement rims. Much fewer broken red ooids were observed than gray ooids (Fig. 4b).

The EPMA backscattered electron images show that the material distribution within ooids is inhomogeneous (Fig. 5), and the EPMA examination reveals the element composition of different minerals (Table 1) in oolitic grainstones. Ooids are mainly composed of calcite (gray color in BSE images, Fig. 5). Mineral displaying average contents of $57.56 \mathrm{wt} \% \mathrm{CaO}(59.58 \mathrm{wt} \%$ in total) supposes to be calcite crystal. Minor oxides in calcite are $0.49 \mathrm{wt} \% \mathrm{MgO}, 0.37 \mathrm{wt} \% \mathrm{SiO}_{2}$ and $0.91 \mathrm{wt} \% \mathrm{FeO}$, which may come from adjacent quartz grains and ferruginous minerals. The second abundant mineral among ooids is quartz which exhibits dark-gray color in BSE images. Particles contain an average chemical composition of $99.16 \mathrm{wt} \% \mathrm{SiO}_{2}$ and $0.26 \mathrm{wt} \%$ $\mathrm{CaO}$ belong to quartz particles which occur as the nuclei or in the cortex of some ooids. There are some ferruginous mineral scattered randomly in ooids (white color in Fig. 5). These particles have significantly high contents in $\mathrm{FeO}$ (80.61 wt\% with $89.00 \mathrm{wt} \%$ in total). The minor oxide concentrations in this mineral are $3.53 \mathrm{wt} \% \mathrm{SiO}_{2}$ and $3.46 \mathrm{wt} \% \mathrm{CaO}$. From the base (Fig. 5a) to the top (Fig. 5b) of a single oolitic grainstone bed, the rock color becomes more pinkish as the concentration of ferruginous mineral increases.

\subsection{Morphology and distribution of ferruginous minerals}

Ferruginous mineral with diameter ranging from hundreds of nanometers to tens of microns are randomly scattered or gathered in ooids (Figs. 6, 7). Two distinguishing morphologies, euhedral crystals and aggregated spheroids, of these minerals are identified through SEM-EDS examination. Euhedral crystals are generally found in the calcium nuclei of ooids, and usually range from several to tens of microns (Fig. 6a-c). They display regular five to six-sided edges in polished thin sections (Fig. 6d). In several cases, this type of iron oxide depicts concentric zones that differ in thickness, size and possibly in chemical composition (Fig. $6 \mathrm{e}, 6 \mathrm{f})$. The inner zones have irregular edges in contrast with regular six-sided margin of the outer zones (Fig. 6f). Spheroid aggregates randomly occur in the whole ooids (Fig. 7), and can reach to a high proportion. Every single aggregate consists of fine amorphous ferruginous spheroids with diameters around or lesser than $1 \mu \mathrm{m}$ (Fig. 7c). The arrangements of the individual ferruginous spheroids are mostly disordered. What is more, at or near spheroid-to-spheroid contacts, there are bridge-like iron oxides exhibiting different brightness with spheroids (Fig. 7c).

The ferruginous minerals occur mostly in ooids and rarely in cements (Figs. 6, 7). Both euhedral crystals and aggregated spheroids distribute randomly in ooids, they can form a whole concentric layer or not (Fig. 7a). The amount and occurrence of them in different ooids are also random. In ooids with quartz nuclei, ferruginous mineral is absent in the nuclei but scatters among the cortex (Fig. 7b, 7d). However, in ooids with calcium nuclei, ferruginous mineral occurs in whole ooids (Fig. 6a, 6b).

Interestingly, in SEM-EDS analysis, ferruginous mineral shows enrichment in S (over $30 \mathrm{cps} / 0.10 \mathrm{wt} \%$ ) content relative to surrounding matrix, which contains no more than 30cps $/ 0.05 \mathrm{wt} \% \mathrm{~S}$ (Fig. 8).

\section{Discussion}

\subsection{Chronostratigraphy of the Menqu section}

The Nieniexiongla Formation and the overlain Pupuga Formation can be divided by their distinct characteristics of lithology, bioclastics and $\delta^{13} \mathrm{C}$ values (Han, Hu, Li, \& Garzanti, 2016; Han, Hu, Kemp, \& Li, 2018).

The Lithiotis -rich interval occurs in the top of the Pupuga Formation. This horizon appears extensively in the Lower Jurassic successions in the Tethys realm and can be used as a mark of biostratigraphic correlation (Han, Hu, Li, \& Garzanti, 2016). The Pupuga Formation consists mainly of medium- to thick-bedded 
(20-50 cm-thick) limestones with abundant bioclastics, e.g., corals, sponges and bivalves. In contrast, the Nieniexiongla Fm. is composed mainly of thin to medium bedded ( $\sim 10 \mathrm{~cm}$-thick) oolitic grainstones with a few sandstone intercalations (Han, Hu, Li, \& Garzanti, 2016). The upper Nieniexiongla Formation reveals an abundance of storm deposits (Han, Hu, Kemp, \& Li, 2018). The base of Nieniexiongla Formation is coincided with the onset of negative excursion of the carbon isotope, which was interpreted as the onset of Toarcian Oceanic Anoxic Event (Han, Hu, Kemp, \& Li, 2018). A negative carbon isotope excursion of 2.5magnitude of about ${ }^{\sim}-1.5 \delta^{13} \mathrm{C}_{\text {carb }}$ (Han, Hu, Kemp, \& Li, 2018).

In Menqu section, all the above outlined transitions were found at $\sim 11.7 \mathrm{~m}$. From 0 to $11.7 \mathrm{~m}$ of the section, the lithologies are mainly medium- to thick-bedded bioclastic grainstones with a limestone bed yielding rich Lithiotis (Fig. 2d). The radiation of the Lithiotis fauna is a global sedimentary event during the Pliensbachian (Franceschi et al., 2014), which demonstrates an Early Jurassic age of this interval. From $11.7 \mathrm{~m}$ to top of the section, the lithologies change dramatically as thin to medium bedded limestones with sandstone intercalations (Fig. 2). Hummocky cross-beddings were found in these sandstone layers, indicating strong storm wave influences. $\delta^{13} \mathrm{C}_{\text {carb }}$ values changed significantly at $\sim 12 \mathrm{~m}$ to average 2.19 interval below $11.7 \mathrm{~m}$ and 1.40date the Menqu section as Early Jurassic age and reveal that the boundary of Pupuga and Nieniexiongla formations is at $\sim 11.7 \mathrm{~m}$. All the studied oolitic grainstones are from the Lower Jurassic Nieniexiongla Formation.

\subsection{Pseudomorphic transformation from pyrites to hematites}

The red color and chemical composition of the ferruginous minerals indicate that they are iron oxides, i.e. hematites (Franke \& Paul, 1980; Préat, Mamet, De Ridder, Boulvain, \& Gillan, 2000; Mamet \& Préat, 2006; $\mathrm{Hu}, 2013)$. The significantly viable sizes as well as the euhedral and spheroidal forms of the hematites rule out that the minerals had been transported into the basin to be combined by carbonates to form ooids. Absence of hematite in the matrix of the Nieniexiongla oolitic grainstones further demonstrates that they were not authigenetically formed in the water masses but grew particulate within the ooids.

Sulfur detected from the hematites could indicate that they were transformed from precursor pyrites (Lu et al., 2005; Soliman \& El Goresy, 2012). The preservation of framboidal morphology and bridge-like ferruginous minerals at or near spheroid-to-spheroid contacts also indicates complete pseudomorphic transformation from pyrite to hematite (Lougheed \& Mancuso, 1973; Mader, 2006; Huang et al., 2019). Framboidal pyrites associated with euhedral pyrite are normally regarded as authigenic pyrites (e.g. Lougheed \& Mancuso, 1973; Wilkin \& Barnes, 1997; Merinero, Lunar, Somoza, Díaz-del-Río, \& Martínez-Frías, 2009; Soliman \& El Goresy, 2012; Wang, Huang, Wang, Feng, \& Huang, 2013). In many cases, framboidal pyrite aggregates have been observed to completely convert to hematite pseudomorphs (Mader, 2006) or other iron mineral pseudomorphs (Soliman \& El Goresy, 2012). Ferruginous minerals at or near spheroid-to-spheroid contacts might be the result of leaching of interstitial hematite, the leaching may exhume the framboidal fabric (Mader, 2006).

The residual sulfur should attribute to leaching and chemical weathering of pyrite which are very common and have been well documented before (Lu et al., 2005; Soliman \& El Goresy, 2012). Most of these researches reported that sulfur in pyrite is transferred to sulfuric and sulfate during oxidation and dissolved in pore water (Weber et al., 2004). The low proportion of residual sulfur in our study suggests high conversion ratio of hematite to pyrite, which means intensely leaching and/or chemical weathering. In the last phase of weathering, only a minor part of sulfur remains as sulfate mineral, but the total mass of iron would not be changed considering iron is rather immobile during weathering ( $\mathrm{Lu}$ et al., 2005).

\subsection{The formation of pyrite}

The formation of pyrite must be under anoxic environments (Berner, 1984; Wilkin \& Barnes, 1997; Suits \& Wilkin, 1998; Kraal, Burton, \& Bush, 2013). However, the Nieniexiongla oolitic grainstones were deposited in mid-ramp environment with periodical influences with storm wave (Han, Hu, Kemp, \& Li, 2018). Additionally, a large amount of broken ooids and the sparry calcite cement would recommend highly agitated sea water. Therefore, it can concluded that the water column was well ventilated and thus hardly to be anoxic 
to facilitate the formation of pyrites.

On the other hand, pyrites are thought to have close connection with organic matter (Berner, De Leeuw, Spiro, Murchison, \& Eglinton, 1985; Raiswell \& Berner, 1986; Rickard, 2012; Wei, Chen, Wang, Yu, \& Tucker, 2012). Especially iron-framboids need organic-rich systems suggesting that organics would make a substantial contribution in their formation (Wignall, Newton, \& Brookfield, 2005; Cavalazzi et al., 2012). As organic matter decomposition continues after sediment deposition through sulphate-reducing bacteria, it leads to reduction of dissolved interstitial sulphate to $\mathrm{H}_{2} \mathrm{~S}$, which compounds with active iron to form pyrites. Meanwhile, intermediate products, $\mathrm{H}_{2} \mathrm{~S}$ and iron sulphides, also need reduced environment, or they would be oxidatively destroyed (Berner, De Leeuw, Spiro, Murchison, \& Eglinton, 1985).

In the case of Menqu, iron minerals are barely found in cements and muds filling in the skeletal chambers, which indicate that the pyrites did not form in the water column. Additionally, the iron minerals are not concentrated around the cracks filled with sparite calcites, which might form during the compaction of the sediments. We suggest that neither the exotic fluids intrusion nor internal remobilized material after lithification of the oolitic grainstones are responsible for the formation of pyrites. Therefore, the timing of the pyrite formation was after the deposition but before the lithification of the rocks. Pore water under reduced condition could provide active iron and $\mathrm{HS}^{-}$(under euxinic condition) to form pyrites. However, the pyrites in Nieniexiongla grainstones are not concentrated on the surface of the ooids but randomly distributed in the cortex and nuclei of the ooids, which indicates the materials remobilized from the ooids played more important roles.

Three principal factors that limit the amount of pyrites are organic matter, active iron and dissolved sulphate (Berner, De Leeuw, Spiro, Murchison, \& Eglinton, 1985). Organic carbon comes from a variety source of autochthonous or allochthonous. Allochthonous organic carbon is terrestrial origin or detrital form, such as plant debris and animal fragments. Autochthonous organic carbon originates mainly from primary production of the pelagic organisms (Zaborska et al., 2016). Very few fossils of marine microfossils or other kinds of organic matters were observed in the Nieniexiongla granistones. However, more studies on ancient and modern cases have revealed that the microorganisms are involved to form ooids (Pacton et al., 2012; Summons et al., 2013; Barale, d'Atri, \& Martire, 2013; Li, Yan, Algeo, \& Wu, 2013; Li et al., 2017). Therefore, we suggest that the decomposition of the microorganisms within the ooids by bacterial sulfate-reducing (BSR) provides the $\mathrm{HS}^{-}$. Furthermore, the oxygenation of organic matters would produce spaces for the intrusion of pore water with sufficient $\mathrm{Fe}^{2+}$ to facilitate the pyrite deposition.

\subsection{Differences of pyrites in nuclei and cortex}

Framboidal pyrites distributed in both cortex and nuclei of the ooids. In contrast, euhedral pyrites were found only in the nuclei composed of carbonate fragments. Euhedral pyrites show concentric fabrics caused by elements concentration indicating multi-stage growth of these minerals, which could lead to significantly larger size of them than framboid pyrites. The early postsedimentary fluids would lead to pyrite overgrowths, and generate chemical zones in pyrites (Agangi, Hofmann, \& Wohlgemuth-Ueberwasser, 2013). Previous studies documented that later pyrite often overgrows earlier generations of pyrite resulting in zoned pyrite with different trace elements patterns during hydrothermal fluid-flow processes (Thomas et al., 2011). However, there are not any Jurassic volcanic rocks or other clues of hydrothermal activities recorded in the southern zone of Tibetan Himalayas. Nevertheless, framboid aggregates can transfer to euhedral crystals through continuous growth of the constituent microcrystals (Ostwald \& England, 1979; Bailey et al., 2010; Soliman \& El Goresy, 2012; Wacey et al., 2015). The Nuclei are also a more open system relative to tightly packed cortex which is more appropriate for the formation of framboids in a close system (Merinero, Lunar, Somoza, Díaz-del-Río, \& Martínez-Frías, 2009). This study therefore suggests that in the Nieniexiongla grainstones, the euhedral pyrites in the ooid nuclei were transferred from original framboids.

\subsection{The modification of ooids by sulfate-reducing bacteria}

The biosignature examination of modern Bahamian ooids revealed that there are diverse microbes including photoautotrophs, heterotrophs, and sulfate-reducing bacteria contained in ooids (Summons et al., 2013; 
Diaz, Piggot, Eberli, \& Klaus, 2013; Diaz et al., 2014; O'Reilly et al., 2016). Although sulfate-reducing bacteria may not contribute significantly in carbonate biomineralization or only play as an unimportant part in cyanobacteria dominated biofilm (Pacton et al., 2012), but we found that sulfate-reducing bacteria would change the mineral composition of ooids after deposition under suitable conditions. However, most ooids would not be modified by sulfate-reducing bacteria without proper environment with sufficient sulfur and active iron influx. Iron ooids are generally red, their cortex may consist of iron minerals (goethite, hematite, chamosite and so on, Sturesson, Dronov, \& Saadre, 1999; Mücke, 2006), or iron minerals mixed with other minerals (phosphate-rich layers+Fe-oxide-rich layers; Barale, d'Atri, \& Martire, 2013). However, most researches about iron ooid formation indicated that these ooids formed under sufficient iron supplement and agitated hydrodynamic environment (Di Bella et al., 2019), or associated with volcanism activities (basalt extrusions, hydrothermal fluids, volcanic ash) (Sturesson, Dronov, \& Saadre, 1999). We speculate that this kind of red ooids are lack of organic matter and sulfate-reducing bacteria, while Bahamian ooids are lack of iron supplement in proper time.

\section{Conclusion}

Ooids in oolitic grainstones of the Nieniexiongla Formation contain significant proportion of hematite which makes ooids reddish. These hematites exhibit mainly two habits: euhedral crystals and aggregated spheroids (framboids). Euhedral crystals are generally found in the calcium nuclei of ooids, and usually range from several to tens of microns. Aggregated spheroids randomly occur in the whole ooids, the diameter of single amorphous spheroid is around or lesser than $1 \mu \mathrm{m}$.

EPMA examination revealed that the hematite is pseudomorph after pyrite. According to the analysis of sedimentary and diagenetic environment, pyrite formed after the deposition but before the lithification of the rocks. Under anoxic conditions, the decomposition of the microorganisms within ooids by sulfate-reducing bacteria provides $\mathrm{HS}^{-}$irons. Then $\mathrm{HS}^{-}$irons reacted with $\mathrm{Fe}^{2+}$ brought by the intrusion of pore water to deposit pyrite.

Larger euhedral pyrites in nuclei may be transferred from framboid aggregates through continuous growth of the constituent microcrystals, since the space of nuclei is an open system and large enough. The research of reddish ooids in oolitic grainstones of the Nieniexiongla Formation demonstrates that sulfate-reducing bacteria would utilize organic matter within ooids after sedimentation, resulting changes in the mineral composition of ooids.

\section{References}

Agangi, A., Hofmann, A., \& Wohlgemuth-Ueberwasser, C.C. (2013). Pyrite Zoning as a Record of Mineralization in the Ventersdorp Contact Reef, Witwatersrand Basin, South Africa. Economic Geology, 108 , 1243-1272. doi:10.2113/econgeo.108.6.1243

Bailey, J., Raub, T., Meckler, N., Harrison, B., Raub, T., Green, A., \& Orphan, V. (2010). Pseudofossils in relict methane seep carbonates resemble endemic microbial consortia. Palaeogeography, Palaeoclimatology, Palaeoecology, 285 , 131-142. doi:10.1016/j.palaeo.2009.11.002

Barale, L., d'Atri, A., \& Martire, L. (2013). The Role of Microbial Activity In the Generation of Lower Cretaceous Mixed Fe-Oxide-phosphate Ooids from the Provencal Domain, French Maritime Alps. Journal of Sedimentary Research, 83 , 196-206. doi:10.2110/jsr.2013.15

Berner, R.A., De Leeuw, J.W., Spiro, B., Murchison, D.G., \& Eglinton, G. (1985). Sulphate Reduction, Organic Matter Decomposition and Pyrite Formation [and Discussion]. Philosophical Transactions of The Royal Society A: Mathematical, Physical and Engineering Sciences, 315 , 25-38. doi:10.1098/rsta.1985.0027

Berner, R.A. (1984). Sedimentary pyrite formation: An update.Geochimica Et Cosmochimica Acta, 48 , 605-615. doi:10.1016/0016-7037(84)90089-9

Cavalazzi, B., Barbieri, R., Cady, S.L., George, A.D., Gennaro, S., Westall, F., Lui, A., Canteri, R., Rossi, A.P., Ori, G.G., Taj-Eddine, K. (2012). Iron-framboids in the hydrocarbon-related Middle Devonian Hol- 
lard Mound of the Anti-Atlas mountain range in Morocco: Evidence of potential microbial biosignatures. Sedimentary Geology, 263-264 , 183-193. doi:10.1016/j.sedgeo.2011.09.007

Chi Fru, E., Ivarsson, M., Kilias, S.P., Bengtson, S., Belivanova, V., Marone, F., Fortin, D., Broman, C., Stampanoni, M. (2013). Fossilized iron bacteria reveal a pathway to the origin of banded iron formations. Nature communications, 4 , 2050. doi:10.1038/ncomms3050

Cornell, R.M., \& Schwertmann, U. (2003). The iron oxydes: structure, Properties, Reactions, Occurences and Uses: Wiley-VCH.

Davies, P.J., Bubela, B., \& Ferguson, J. (1978). The formation of ooids. Sedimentology, 25 , 703-730. doi:10.1111/j.1365-3091.1978.tb00326.x

Di Bella, M., Sabatino, G., Quartieri, S., Ferretti, A., Cavalazzi, B., Barbieri, R., Foucher, F., Messori, F., Italiano, F. (2019). Modern Iron Ooids of Hydrothermal Origin as a Proxy for Ancient Deposits.Scientific Reports, 9:7017 . doi:10.1038/s41598-019-43181-y

Diaz, M.R., \& Eberli, G. (2018). Decoding the mechanism of formation in marineooids: A review. EarthScience Reviews, 190 . doi:10.1016/j.earscirev.2018.12.016

Diaz, M.R., Van Norstrand, J.D., Eberli, G.P., Piggot, A.M., Zhou, J., \& Klaus, J.S. (2014). Functional gene diversity of oolitic sands from Great Bahama Bank. Geobiology, 12 , 231-249. doi:10.1111/gbi.12079

Diaz, M.R., Piggot, A.M., Eberli, G.P., \& Klaus, J.S. (2013). Bacterial community of oolitic carbonate sediments of the Bahamas Archipelago.Marine Ecology Progress Series, 485 , 9-U30. doi:10.3354/meps10359

Diaz, M.R., Swart, P.K., Eberli, G.P., Oehlert, A.M., Devlin, Q., Saeid, A., \& Altabet, M.A. (2015). Geochemical evidence of microbial activity within ooids. Sedimentology, 62 , 2090-2112. doi:10.1111/sed.12218

Duguid, S.M.A., Kyser, T.K., James, N.P., \& Rankey, E.C. (2010). Microbes and Ooids. Journal of Sedimentary Research, 80 , 236-251. doi:10.2110/jsr.2010.027

Dunham, R.J. (1962). Classification of Carbonates Rocks According to Deposicional texture. American Association of Petroleum Geologists Memoir, 1, 108-121.

Dupraz, C., Reid, R.P., Braissant, O., Decho, A.W., Norman, R.S., \& Visscher, P.T. (2009). Processes of carbonate precipitation in modern microbial mats. Earth-Science Reviews, 96 , 141-162. doi:10.1016/j.earscirev.2008.10.005

Embry, A.F., \& Klovan, J.E. (1971). A late Devonian reef tract on northeastern Banks Island, N.W.T. Bulletin of Canadian Petroleum Geology, 19 , 730-781.

Erşan, Y.Ç., De Belie, N., \& Boon, N. (2015). Microbially induced $\mathrm{CaCO}_{3}$ precipitation through denitrification: An optimization study in minimal nutrient environment. Biochemical Engineering Journal, 101 , 108-118. doi:10.1016/j.bej.2015.05.006

Franceschi, M., Dal Corso, J., Posenato, R., Roghi, G., Masetti, D., \& Jenkyns, H.C. (2014). Early Pliensbachian (Early Jurassic) C-isotope perturbation and the diffusion of the Lithiotis Fauna: Insights from the western Tethys. Palaeogeography Palaeoclimatology Palaeoecology, 410 , 255-263. doi:10.1016/j.palaeo.2014.05.025

Franke, W., \& Paul, J. (1980). Pelagic redbeds in the Devonian of Germany - deposition and diagenesis. Sedimentary Geology, 25 , 231-256. doi:10.1016/0037-0738(80)90043-3

Han, Z., Hu, X.M., Kemp, D.B., \& Li, J. (2018). Carbonate-platform response to the Toarcian Oceanic Anoxic Event in the southern hemisphere: Implications for climatic change and biotic platform demise.Earth and Planetary Science Letters, 489 , 59-71. doi:10.1016/j.epsl.2018.02.017 
Han, Z., Hu, X.M., Li, J., \& Garzanti, E. (2016). Jurassic carbonate microfacies and relative sea-level changes in the Tethys Himalaya (southern Tibet). Palaeogeography, Palaeoclimatology, Palaeoecology, 456 , 1-20. doi:10.1016/j.palaeo.2016.05.012

$\mathrm{Hu}$, X. (2013). Distribution, Types and Origins of Phanerozoic Marine Red Beds. Bulletin of Mineralogy Petrology and Geochemistry, 32, 335-342 (in Chinese with English abstract).

Huang, W.T., Jackson, M.J., Dekkers, M.J., Zhang, Y., Zhang, B., Guo, Z.J., \& Dupont-Nivet, G. (2019). Challenges in isolating primary remanent magnetization from Tethyan carbonate rocks on the Tibetan Plateau: Insight from remagnetized Upper Triassic limestones in the eastern Qiangtang block. Earth and Planetary Science Letters, 523 :115692. doi:10.1016/j.epsl.2019.06.035

Jadoul, F., Berra, F., \& Garzanti, E. (1998). The Tethys Himalayan passive margin from Late Triassic to Early Cretaceous (South Tibet).Journal of Asian Earth Sciences, 16 , 173-194. doi:10.1016/S07439547(98)00013-0

Javanbakht, M., Wanas, H., Jafarian, A., Shahsavan, N., \& Sahraeyan, M. (2018). Carbonate diagenesis in the Barremian-Aptian Tirgan Formation (Kopet-Dagh Basin, NE Iran): Petrographic, geochemical and reservoir quality constraints. Journal of African Earth Sciences, 144 , 122-135. doi:10.1016/j.jafrearsci.2018.04.016

Kraal, P., Burton, E.D., \& Bush, R.T. (2013). Iron monosulfide accumulation and pyrite formation in eutrophic estuarine sediments. Geochimica Et Cosmochimica Acta, 122 , 75-88. doi:10.1016/j.gca.2013.08.013

Li, F., Yan, J.X., Burne, R.V., Chen, Z.Q., Algeo, T.J., Zhang, W., Tian, L., Gan, Y.L., Liu, K., Xie, S.C. (2017). Paleo-seawater REE compositions and microbial signatures preserved in laminae of Lower Triassic ooids. Palaeogeography Palaeoclimatology Palaeoecology, 486 , 96-107. doi:10.1016/j.palaeo.2017.04.005

Li, F., Yan, J.X., Algeo, T., \& Wu, X.Z. (2013). Paleoceanographic conditions following the end-Permian mass extinction recorded by giant ooids (Moyang, South China). Global and Planetary Change, 105 , 102-120. doi:10.1016/j.gloplacha.2011.09.009

Li, X.H., \& Wang, C.S. (2005). Reinterpretation of the jurassic across the main himalayan ridge norh of nyalam, southern tibet, China. Geological Bulletin of China, 2, 1121-1126 (in Chinese with English abstract).

Lougheed, M.S., \& Mancuso, J.J. (1973). Hematite Framboids in the Negaunee Iron Formation, Michigan; evidence for Their Biogenic Origin.Economic Geology, 68 , 202-209. doi:10.2113/gsecongeo.68.2.202

Lu, L., Wang, R.C., Chen, F.R., Xue, J.Y., Zhang, P.H., \& Lu, J.J. (2005). Element mobility during pyrite weathering: Implications for acid and heavy metal pollution at mining-impacted sites. Environmental Geology, 49 , 82-89. doi:10.1007/s00254-005-0061-8

Mücke, A. (2006). Chamosite, siderite and the environmental conditions of their formation in chamosite-type Phanerozoic ooidal ironstones. Ore Geology Reviews, 28 , 235-249. doi:10.1016/j.oregeorev.2005.03.004

Mader, D. (2006). Diagenetic evolution of opaque and transparent heavy minerals reflecting colour genesis in continental fluvial buntsandstein red beds of the eifel (F.R. Germany). In (Vol. 4, pp. 531-560).

Mamet, B., \& Préat, A. (2006). Iron-bacterial mediation in Phanerozoic red limestones: State of the art. Sedimentary Geology, 185 , 147-157. doi:10.1016/j.sedgeo.2005.12.009

Mariotti, G., Pruss, S.B., Summons, R.E., Newman, S.A., \& Bosak, T. (2018). Contribution of Benthic Processes to the Growth of Ooids on a Low-Energy Shore in Cat Island, The Bahamas. Minerals, 8 , 21. doi: $10.3390 / \min 8060252$

Merinero, R., Lunar, R., Somoza, L., Díaz-del-Río, V., \& Martínez-Frías, J. (2009). Nucleation, growth and oxidation of framboidal pyrite associated with hydrocarbon-derived submarine chimneys: Lessons learned from the Gulf of Cadiz. European Journal of Mineralogy, 21 , 947-961. doi:10.1127/0935-1221/2009/00211956 
Morse, J.W., \& Mackenzie, F.T. (1990). Geochemistry of sedimentary carbonates. Developments in Sedimentology, 48 . doi:10.1016/S0070-4571(08)70330-3

O'Reilly, S.S., Mariotti, G., Winter, A.R., Newman, S.A., Matys, E.D., McDermott, F., Pruss, S.B., Bosak, T., Summons, R.E., Klepac-Ceraj, V. (2016). Molecular biosignatures reveal common benthic microbial sources of organic matter in ooids and grapestones from Pigeon Cay, The Bahamas. Geobiology, 15 , 112-130. doi:10.1111/gbi.12196

Ostwald, J., \& England, B.M. (1979). The Relationship Between Euhedral and Framboidal Pyrite in BaseMetal Sulphide Ores. Mineralogical Magazine, 43 , 297-300. doi:10.1180/minmag.1979.043.326.13

Pacton, M., Ariztegui, D., Wacey, D., Kilburn, M.R., Rollion-Bard, C., Farah, R., \& Vasconcelos, C. (2012). Going nano: A new step toward understanding the processes governing freshwater ooid formation. Geology, $40,547-550$ doi:10.1130/G32846.1

Pan, G., Ding, J., Yao, D., Wang, L., 2004. The Guide Book of 1:1,500,000 Geologic Map of the QinghaiXizang (Tibet) Plateau and Adjacent Areas. Chengdu Cartographic Publishing House, Chengdu (in Chinese).

Posth, N.R., Konhauser, K.O., \& Kappler, A. (2013). Microbiological processes in banded iron formation deposition. Sedimentology, 60 , 1733-1754. doi:10.1111/sed.12051

Préat, A., Mamet, B., De Ridder, C., Boulvain, F., \& Gillan, D. (2000). Iron bacterial and fungal mats, Bajocian stratotype (Mid-Jurassic, Northern Normandy, France). Sedimentary Geology, 137, 107-126. doi:10.1016/S0037-0738(00)00101-9

Raiswell, R., \& Berner, R.A. (1986). Pyrite and organic matter in Phanerozoic normal marine shales. Geochimica Et Cosmochimica Acta, 50 , 1967-1976. doi:10.1016/0016-7037(86)90252-8

Rickard, D. (2012). Chapter 6 - Sedimentary Pyrite. In D. Rickard (Ed.), Developments in Sedimentology (Vol. 65, pp. 233-285): Elsevier.

Soliman, M.F., \& El Goresy, A. (2012). Framboidal and idiomorphic pyrite in the upper Maastrichtian sedimentary rocks at Gabal Oweina, Nile Valley, Egypt: Formation processes, oxidation products and genetic implications to the origin of framboidal pyrite. Geochimica Et Cosmochimica Acta, 90 , 195-220. doi:10.1016/j.gca.2012.05.004

Sturesson, U., Dronov, A., \& Saadre, T. (1999). Lower Ordovician iron ooids and associated oolitic clays in Russia and Estonia: A clue to the origin of iron oolites? Sedimentary Geology, 123 , 63-80. doi:10.1016/S00370738(98)00112-2

Suits, N.S., \& Wilkin, R.T. (1998). Pyrite formation in the water column and sediments of a meromictic lake. Geology, 26 , 1099-1102. doi:10.1130/0091-7613(1998)026<1099:pfitwc >2.3.co;2

Summons, R.E., Bird, L.R., Gillespie, A.L., Pruss, S.B., Roberts, M., \& Sessions, A.L. (2013). Lipid biomarkers in ooids from different locations and ages: evidence for a common bacterial flora.Geobiology, 11 , 420-436. doi:10.1111/gbi.12047

Thomas, H.V., Large, R.E., Bull, S.W., Maslennikov, V., Berry, R.F., Fraser, R., Froud, S., Moye, R. (2011). Pyrite and Pyrrhotite Textures and Composition in Sediments, Laminated Quartz Veins, and Reefs at Bendigo Gold Mine, Australia: Insights for Ore Genesis. Economic Geology, 106 , 1-31. doi:10.2113/econgeo.106.1.1

Wacey, D., Kilburn, M., Saunders, M., Cliff, J., Kong, C., Liu, A., Matthews, J., Brasier, M. (2015). Uncovering framboidal pyrite biogenicity using nano-scale CN org mapping. Geology, 43 , 27. doi:10.1130/G36048.1

Wan, X.Q. (1989). Jurassic foraminifera from Nyalam, Xizang (Tibet), China. Acta Micropalaeontologica Sinica 6 , 139-152 (in Chinese with English abstract).

Wang, C.S., Li, X.H., Hu, X. M., Wan, X.Q., Yin, J.R., Huang, Y.J., Huang, S.J., Li, G.B. (2005). Tethyan Himalayan Sedimentary Geology and Continental Paleoceanography. Geological Publishing House, Beijing 
(373 pp., in Chinese).

Wang, P.K., Huang, Y.J., Wang, C.S., Feng, Z.H., \& Huang, Q.H. (2013). Pyrite morphology in the first member of the Late Cretaceous Qingshankou Formation, Songliao Basin, Northeast China. Palaeogeography Palaeoclimatology Palaeoecology, 385 , 125-136. doi:10.1016/j.palaeo.2012.09.027

Weber, P.A., Stewart, W.A., Skinner, W.M., Weisener, C.G., Thomas, J.E., \& Smart, R.S.C. (2004). Geochemical effects of oxidation products and framboidal pyrite oxidation in acid mine drainage prediction techniques.Applied Geochemistry, 19 , 1953-1974. doi:10.1016/j.apgeochem.2004.05.002

Wei, H.Y., Chen, D.Z., Wang, J.G., Yu, H., \& Tucker, M.E. (2012). Organic accumulation in the lower Chihsia Formation (Middle Permian) of South China: Constraints from pyrite morphology and multiple geochemical proxies. Palaeogeography Palaeoclimatology Palaeoecology, 353 , 73-86. doi:10.1016/j.palaeo.2012.07.005

Wignall, P.B., Newton, R., \& Brookfield, M.E. (2005). Pyrite framboid evidence for oxygen-poor deposition during the Permian-Triassic crisis in Kashmir. Palaeogeography Palaeoclimatology Palaeoecology, 216 , 183188. doi:10.1016/j.palaeo.2004.10.009

Wilkin, R.T., \& Barnes, H.L. (1997). Pyrite formation in an anoxic estuarine basin. American Journal of Science, 297 , 620-650. doi:10.2475/ajs.297.6.620

Yin, J.R. (2010). Jurassic Ammonites of Tibet. Geological Publishing House, Beijing (247 pp.; in Chinese with English abstract).

Zaborska, A., Wlodarska-Kowalczuk, M., Legeżyńska, J., Jankowska, E., Winogradow, A., \& Deja, K. (2016). Sedimentary organic matter sources, benthic consumption and burial in west Spitsbergen fjords - Signs of maturing of Arctic fjordic systems? Journal of Marine Systems, 180 , 112-123. doi:10.1016/j.jmarsys.2016.11.005

Zhang, S., Henehan, M.J., Hull, P.M., Reid, R.P., Hardisty, D.S., Hood, A.V.S., \& Planavsky, N.J. (2016). Investigating controls on boron isotope ratios in shallow marine carbonates. Earth and Planetary Science Letters, 458 , 380-393. doi:10.1016/j.epsl.2016.10.059

\section{Figure and table captions}

Fig. 1. Simplified tectonic map of the southern Tibet (modified from Pan et al., 2004). Location of the study area is indicated by a red star.

Fig. 2. Photos are showing: (a) bioclastic grainstone, (b) bioclastic wackestone, (c) coral framestones, (d) shell bed mainly composed of Lithiotis, (e) mudstone and grainstone, (f) sand lens and erosive base. The contact between mudstones and grianstones is erosive.

Fig. 3. Correlation of stratigraphic distribution of carbonate carbon isotopes of the Menqu section and distribution of organic carbon isotopes of the Nianduo section (Han, Hu, Kemp, \& Li, 2018). The blue dashed line means the boundary between the Pupuga Formation and the Nieniexiongla Formation.

Fig. 4. Photo of oolitic grainstones from Nieniexiongla Formation (plane polarized light microscopy image).

Fig. 5. EPMA points of ooilitic grainstones (polished thin section, EPMA backscattered electron image, results of green points with numbers could be seen in Table 1). (a) 17MQ56-03:1 and 17MQ56-03:2 are ferruginous mineral, 17MQ56-03:3 is quartz; (b) 17MQ66-02:1, 17MQ66-02:2, 17MQ66-02:3 and 17MQ66$02: 4$ are all ferruginous mineral.

Fig. 6. (a) ooid with euhedral ferruginous minerals in nuclei and ferruginous spheroids in cortex (polished thin section, SEM backscattered electron image), (b) ooid with euhedral ferruginous (polished thin section, SEM backscattered electron image), (c) euhedral ferruginous particles (fresh fragment, SEM image), (d) regular six-sided euhedral ferruginous particles (polished thin section, SEM backscattered electron image), (e, f) euhedral ferruginous minerals show concentric structure (polished thin section, SEM backscattered electron image). 
Fig. 7. (a) ferruginous particles make up of a concentric layer around the cortex (polished thin section, SEM backscattered electron image), (b) ooids contain ferruginous particles with quartz nuclei (polished thin section, SEM backscattered electron image), (c) ferruginous aggregated spheroids (fresh fragment, SEM backscattered electron image), (d) ooids contain ferruginous particles with different nuclei (polished thin section, SEM backscattered electron image).

Fig. 8. Linear scan of sulfur and iron distribution of a ferruginous particle by SEM-EDS. Polished thin section, SEM backscattered electron image.

Table 1. Results of EPMA analysis of different minerals in red ooid grainstones (oxide values are given in molar).

\begin{tabular}{|c|c|c|c|c|c|c|c|c|c|c|c|c|c|c|}
\hline Data & $\mathrm{Ta}_{2} \mathrm{O}$ & $\mathrm{iO}_{2}$ & $\mathrm{SiO}_{2}$ & $\mathrm{oO}$ & $\mathrm{MgO}$ & $\mathrm{Cr}_{2} \mathrm{O}_{3}$ & $\mathrm{P}_{2} \mathrm{O}_{5}$ & $\mathrm{NiO}$ & $\mathrm{Al}_{2} \mathrm{O}_{3}$ & $\mathrm{MnO}$ & $\mathrm{K}_{2} \mathrm{O}$ & $\mathrm{FeO}$ & $\mathrm{CaO}$ & \\
\hline MQ66-02-2 & 17 & 3 & 3.89 & 15 & 36 & 0.02 & 0.07 & & 0.73 & 1 & 8 & .31 & 79 & \\
\hline & 27 & & & & & & & 0.01 & & & & & & \\
\hline 6-01-1 & 0.09 & & 5.21 & 13 & 34 & & 10 & 0.02 & & .03 & & & 62 & \\
\hline 6-04-1 & 05 & 0.00 & 2.65 & 16 & 0.54 & 0.00 & 0.14 & & 0.22 & 0.03 & .02 & 2.25 & 1.72 & \\
\hline 66-04-2 & 0.16 & & 3.52 & 15 & 0.34 & 0.02 & 0.10 & 0.05 & 0.41 & & 2 & 76 & .61 & \\
\hline $6-04-3$ & 0.30 & & 9 & 14 & & & & 0.02 & & 0.08 & 9 & & .08 & \\
\hline & 8 & & & 7 & & & & .08 & & 0.06 & & & .18 & \\
\hline & 0.10 & & & & & & & 0.01 & & 0.02 & & & 73 & \\
\hline & 0 & 0.04 & 3.90 & 1 & 4 & 0. & 0.12 & & & 0.04 & & & 4.98 & \\
\hline & 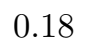 & 0.02 & & & & & & 0.06 & & 0.01 & & & 1.78 & \\
\hline & 0.04 & & 8 & 99 & 9 & 0. & & 0.05 & 0.2 & & & & 1.78 & \\
\hline & ( 21 & 0.07 & 5.45 & & 3 & & 0.16 & & & 0.04 & 9 & & 8.28 & \\
\hline & 7 & 0.04 & 3.27 & 09 & 7 & 0 & 0.11 & & 0. & & 1 & & 1.93 & \\
\hline $6-2$ & 0.07 & & 350 & 10 & .28 & & 0 & & & 0.02 & 0.04 & & 4.56 & \\
\hline $6-3$ & 0.10 & & 4 & 08 & 49 & & 0 & & & 0.02 & 5 & & 1.64 & \\
\hline & 0.06 & & & 03 & & & & & & 0.03 & 0.02 & & 1.69 & \\
\hline & 0.01 & 0.01 & 3.06 & 0.13 & 0.20 & & & & & 0.01 & & & 1.97 & \\
\hline & 0.16 & & & & & & & & & 0.09 & 0.03 & & 2.29 & \\
\hline & 0 & 0.00 & & & & $0 .($ & & 0.03 & & 0.08 & 3 & & 2.88 & \\
\hline & & 0.05 & & 0.19 & 0.18 & & & & 0.0 & 0.02 & 3 & & 7.47 & \\
\hline & & 0.03 & 2 . & 1 & 0.20 & 0.02 & & & & & .02 & & 1.85 & \\
\hline & & & & & & 0.03 & & 0.03 & & 0.00 & & & 2.75 & \\
\hline $4-2$ & 0 & 2 & & & 0.28 & & & 0.16 & & 0.14 & 11 & & 4.19 & \\
\hline & & & & & & 0 & & 16 & & 0.14 & 9 & & 8.28 & \\
\hline & & 00 & & & & & & 01 & & 0.00 & 1 & 11 & 1.61 & \\
\hline & & 0.03 & & & & & & 0.05 & & 0.04 & 0.06 & & .46 & \\
\hline & $\mathrm{N}$ & $\mathrm{TiO} 2$ & $\mathrm{Si}$ & $\mathrm{CoO}$ & $\mathrm{MgO}$ & & $\mathrm{P} 2 \mathrm{O} 5$ & $\mathrm{NiO}$ & & $\mathrm{MnO}$ & $\mathrm{K} 2 \mathrm{O}$ & & $\mathrm{CaO}$ & \\
\hline & 0.02 & & 0.85 & 0.04 & 0.44 & 0.04 & 0.06 & & & 0.04 & & 7 & 57.34 & \\
\hline & 0.06 & & 0.11 & 0.03 & 0.79 & 0.07 & & & & 0.01 & 0 & & 58 & \\
\hline & 0.02 & & 0.03 & & 0.22 & 0.05 & 0 & 0.00 & 0.02 & 0.06 & 2 & & & \\
\hline & & 0.04 & 0.03 & & & & & 0.04 & & 0.08 & & & 99 & \\
\hline & & 0.04 & & 0. & & & & 0.07 & 0. & 0.00 & & & 41 & \\
\hline & & 0.11 & 0. & 0.02 & 0.60 & 0.01 & 0.02 & 0.02 & 0.07 & & & & .21 & \\
\hline & 0.0 & 0.01 & 0.2 & & 0.64 & & 0.03 & & 0.10 & 0.05 & 0.01 & 1. & .03 & \\
\hline$-06-3$ & 0.02 & & 0.4 & & 0.57 & 0. & & & 0.0 & & 0. & & 41 & \\
\hline & 0.0 & & 1.2 & & & & & & & 0.08 & 0. & & 59.99 & \\
\hline & & & & & & & & & & & 0. & & 54.41 & \\
\hline & & & 0.3 & & & 0.0 & 0.0 & 0.03 & $0 .($ & & 0.01 & 0.91 & 57.56 & \\
\hline $\operatorname{Data}(w t \%)$ & $\mathrm{Na} 2 \mathrm{O}$ & $\mathrm{TiO} 2$ & $\mathrm{SiO} 2$ & $\mathrm{CoO}$ & $\mathrm{MgO}$ & $\mathrm{Cr} 2 \mathrm{O} 3$ & $\mathrm{P} 2 \mathrm{O} 5$ & $\mathrm{NiO}$ & $\mathrm{Al} 2 \mathrm{O} 3$ & $\mathrm{MnO}$ & $\mathrm{K} 2 \mathrm{O}$ & $\mathrm{FeO}$ & $\mathrm{CaO}$ & \\
\hline
\end{tabular}




\begin{tabular}{|c|c|c|c|c|c|c|c|c|c|c|c|c|c|c|}
\hline $\operatorname{Data}($ wt $\%)$ & $\mathrm{Na}_{2} \mathrm{O}$ & $\mathrm{TiO}_{2}$ & $\mathrm{SiO}_{2}$ & $\mathrm{CoO}$ & $\mathrm{MgO}$ & $\mathrm{Cr}_{2} \mathrm{O}_{3}$ & $\mathrm{P}_{2} \mathrm{O}_{5}$ & $\mathrm{NiO}$ & $\mathrm{Al}_{2} \mathrm{O}_{3}$ & $\mathrm{MnO}$ & $\mathrm{K}_{2} \mathrm{O}$ & $\mathrm{FeO}$ & $\mathrm{CaO}$ & \\
\hline 17MQ56-03-3 & 0.04 & 0.06 & 99.78 & & 0.01 & 0.03 & 0.01 & & 0.07 & & 0.01 & 0.04 & 0.27 & \\
\hline 17MQ56-05-1 & 0.04 & 0.03 & 98.60 & & 0.01 & 0.03 & 0.00 & 0.03 & 0.07 & 0.02 & 0.02 & & 0.40 & \\
\hline 17MQ56-05-2 & 0.05 & & 99.61 & & 0.02 & & & 0.09 & 0.01 & 0.05 & 0.07 & 0.04 & 0.24 & \\
\hline 17MQ56-05-4 & 0.05 & & 98.65 & 0.03 & 0.00 & 0.02 & & 0.08 & 0.05 & 0.02 & 0.02 & & 0.14 & \\
\hline maximum & 0.05 & 0.06 & 99.78 & 0.03 & 0.02 & 0.03 & 0.01 & 0.09 & 0.07 & 0.05 & 0.07 & 0.04 & 0.40 & \\
\hline minimum & 0.04 & 0.03 & 98.60 & 0.03 & 0.00 & 0.02 & 0.00 & 0.03 & 0.01 & 0.02 & 0.01 & 0.04 & 0.14 & \\
\hline average & 0.05 & 0.05 & 99.16 & 0.03 & 0.01 & 0.03 & 0.01 & 0.07 & 0.05 & 0.03 & 0.03 & 0.04 & 0.26 & \\
\hline $\operatorname{Data}(w t \%)$ & $\mathrm{Na} 2 \mathrm{O}$ & $\mathrm{TiO} 2$ & $\mathrm{SiO} 2$ & $\mathrm{CoO}$ & $\mathrm{MgO}$ & $\mathrm{Cr} 2 \mathrm{O} 3$ & $\mathrm{P} 2 \mathrm{O} 5$ & $\mathrm{NiO}$ & $\mathrm{Al} 2 \mathrm{O} 3$ & $\mathrm{MnO}$ & $\mathrm{K} 2 \mathrm{O}$ & $\mathrm{FeO}$ & $\mathrm{CaO}$ & \\
\hline 17MQ66-01-2 & 0.12 & 0.07 & 5.37 & 0.08 & 0.43 & 0.06 & 0.07 & 0.01 & 1.31 & & 0.18 & 59.15 & 16.92 & \\
\hline 17MQ66-01-3 & 0.05 & & 3.28 & 0.12 & 0.37 & 0.04 & 0.05 & & 0.53 & 0.06 & 0.03 & 44.42 & 25.57 & \\
\hline 17MQ66-05-4 & 0.05 & & 2.72 & 0.13 & 0.43 & 0.01 & 0.06 & & 0.43 & & 0.02 & 26.89 & 39.91 & \\
\hline 17MQ56-06-1 & 0.18 & 0.02 & 3.44 & 0.07 & 0.37 & 0.03 & 0.11 & 0.10 & 0.62 & 0.06 & 0.02 & 33.18 & 33.01 & \\
\hline maximum & 0.18 & 0.07 & 5.37 & 0.13 & 0.43 & 0.06 & 0.11 & 0.10 & 1.31 & 0.06 & 0.18 & 59.15 & 39.91 & \\
\hline minimum & 0.05 & 0.02 & 2.72 & 0.07 & 0.37 & 0.01 & 0.05 & 0.01 & 0.43 & 0.06 & 0.02 & 26.89 & 16.92 & \\
\hline average & 0.10 & 0.05 & 3.70 & 0.10 & 0.40 & 0.04 & 0.07 & 0.06 & 0.72 & 0.06 & 0.06 & 40.91 & 28.85 & \\
\hline
\end{tabular}

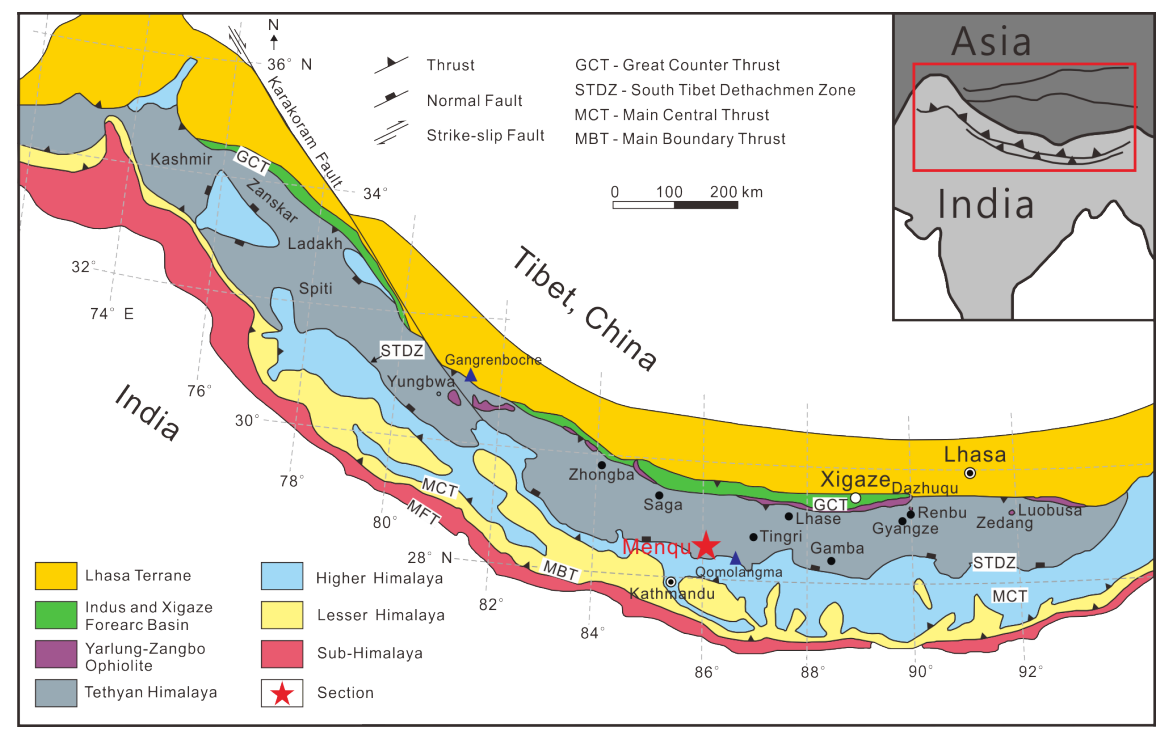



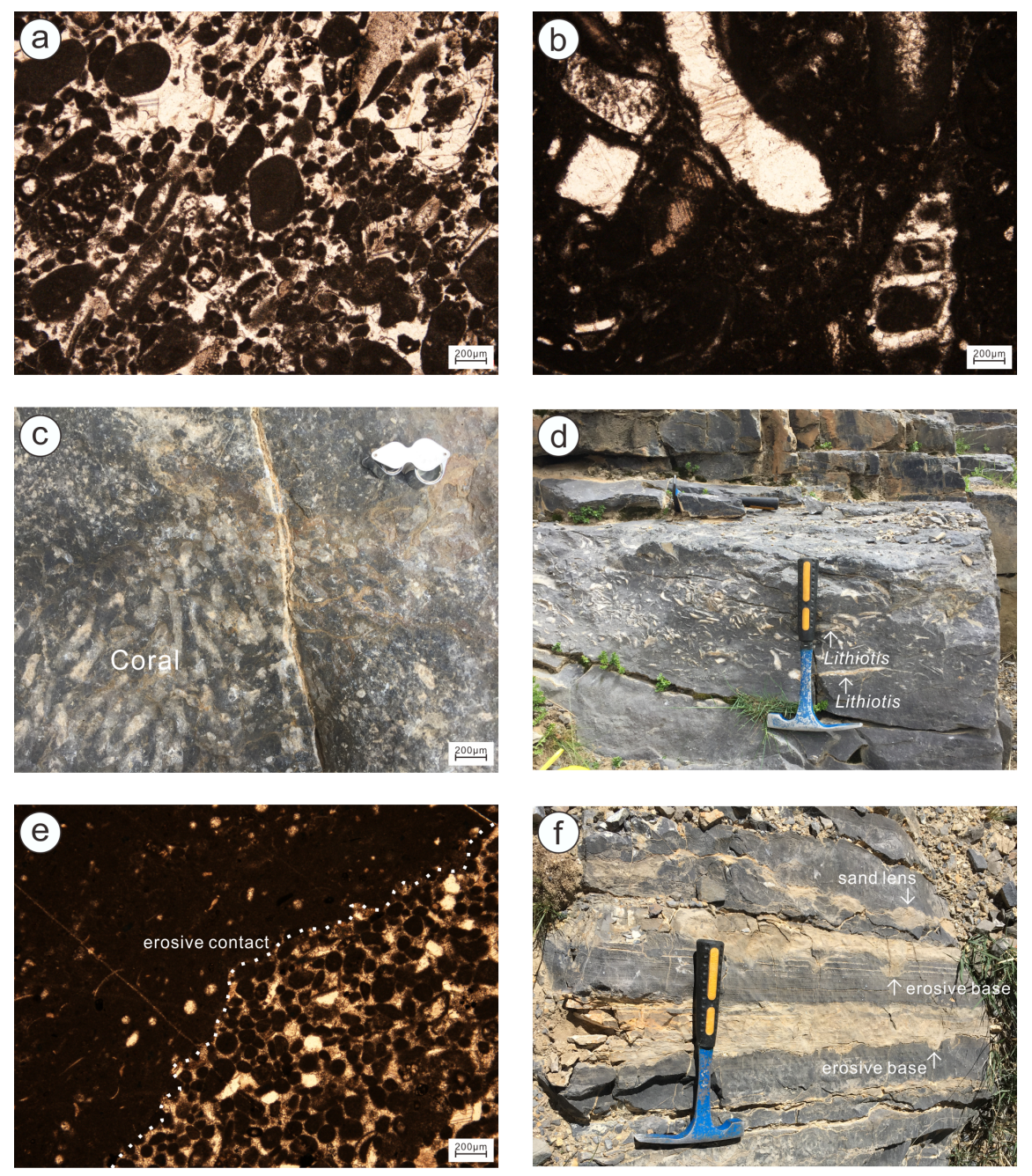

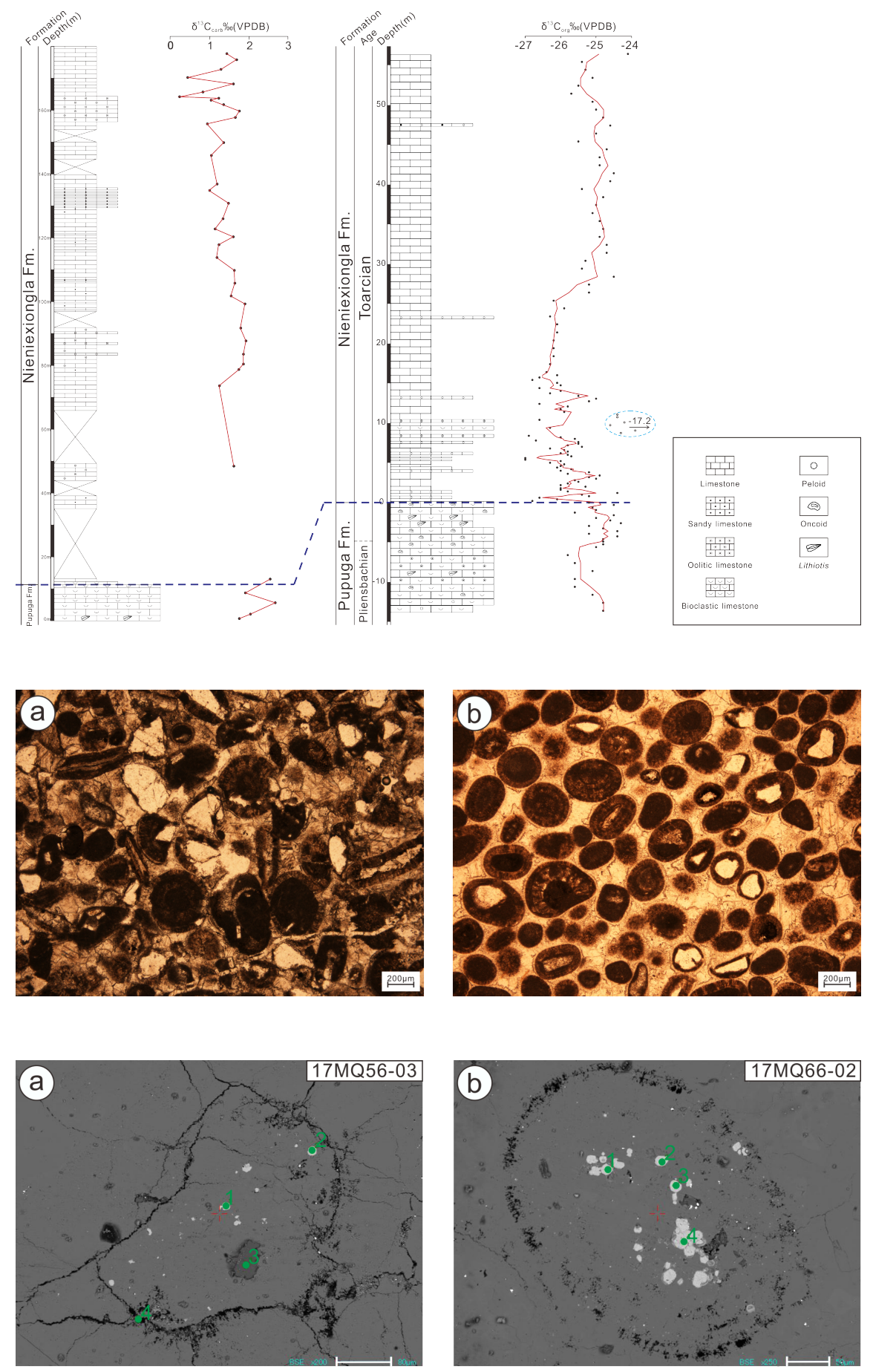

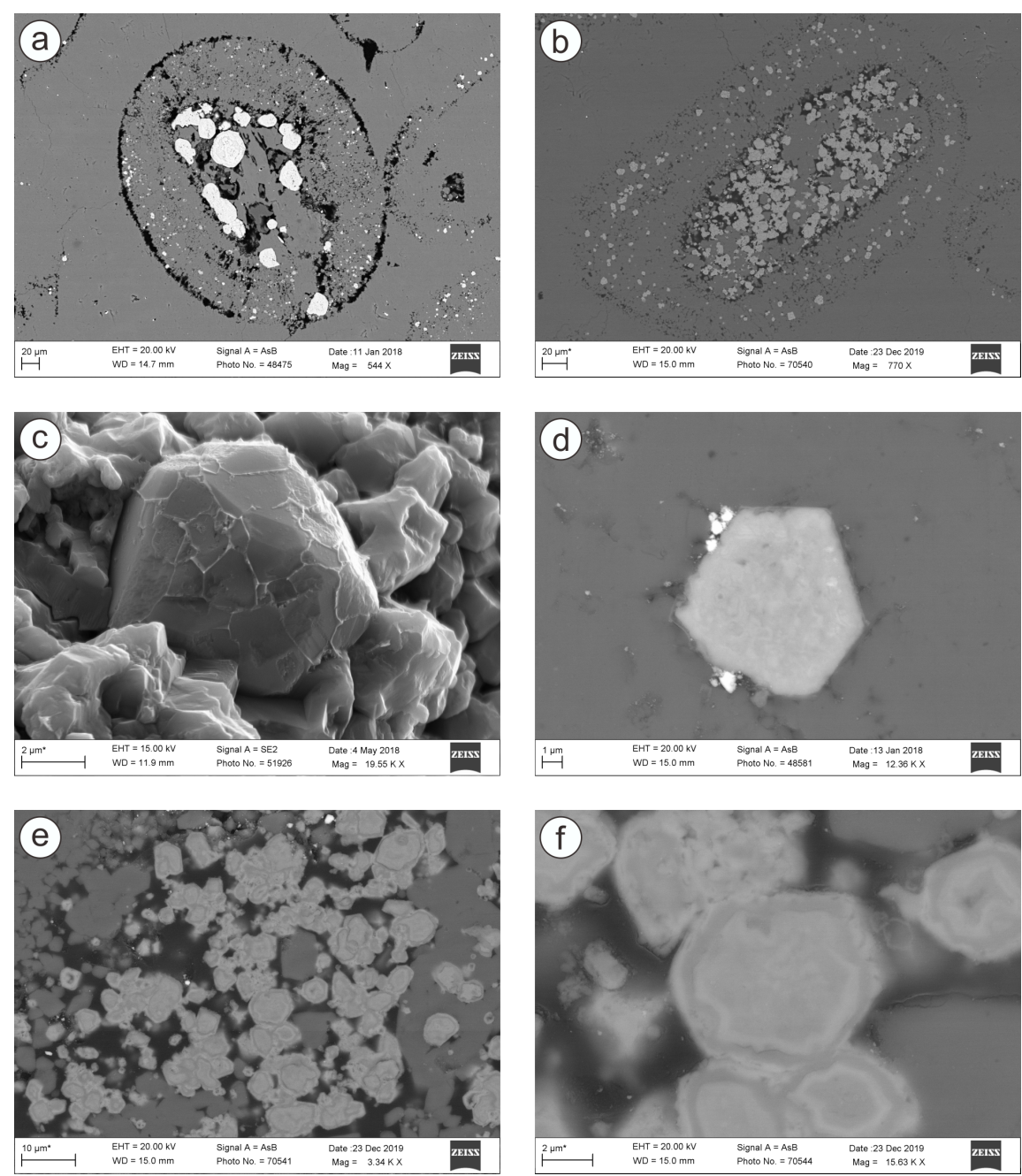

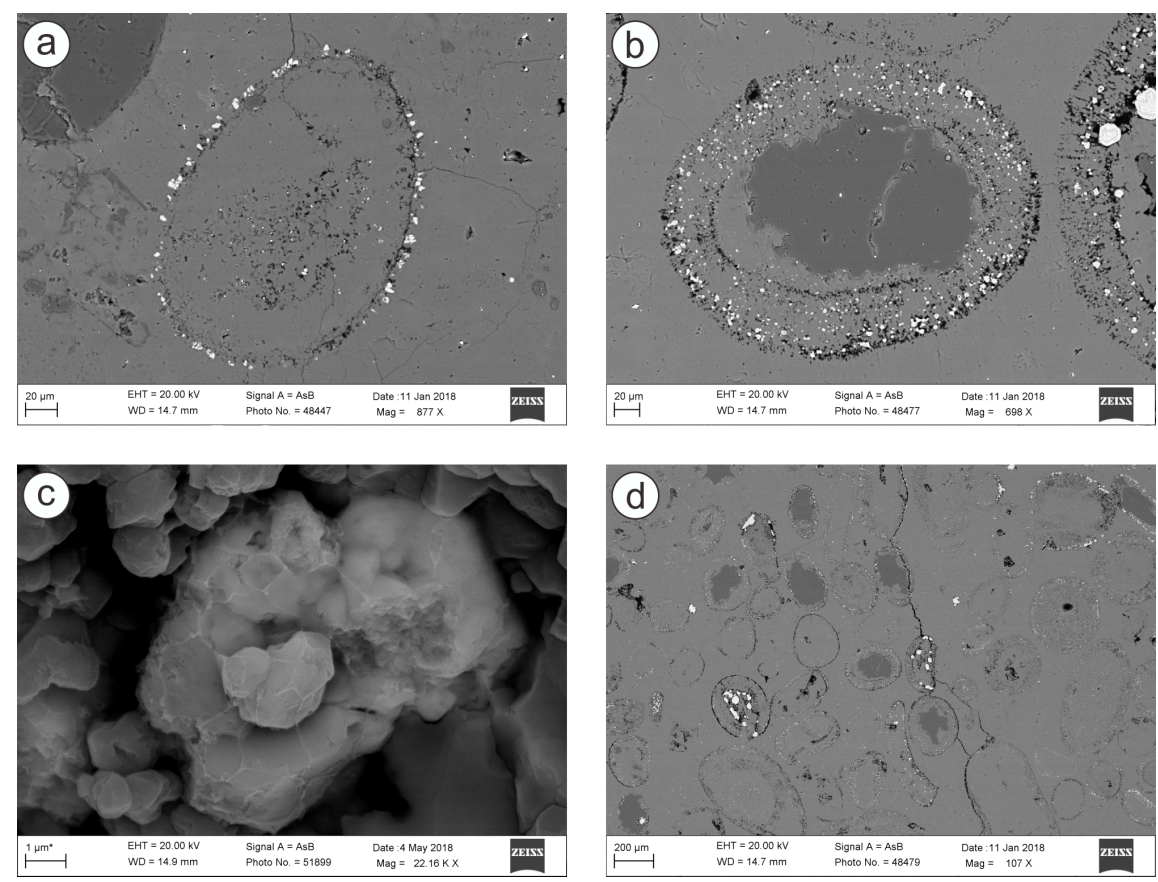

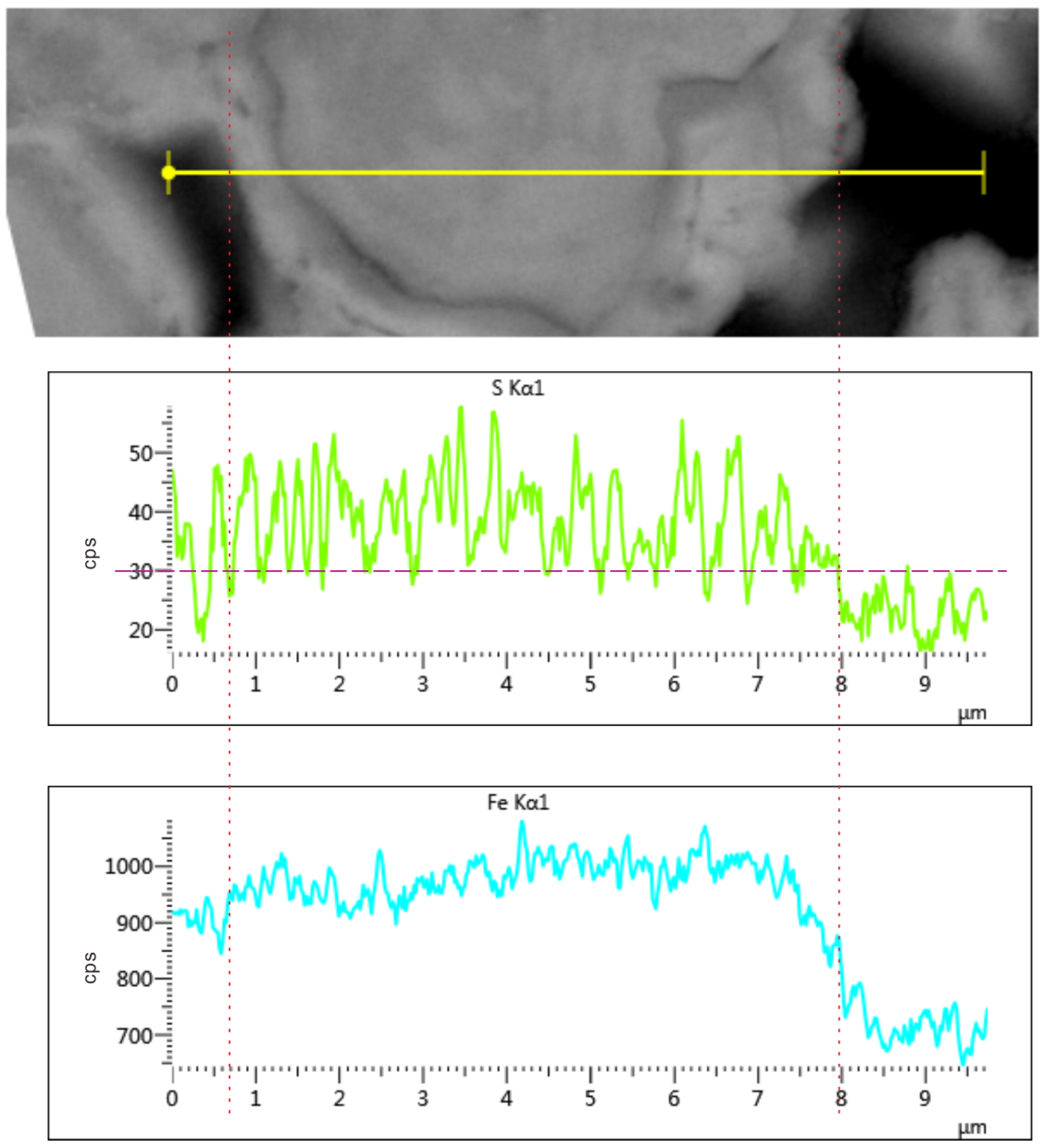